\title{
Assessing the Friendship Quality of Children between the Ages of 9 and 12 Based on Certain Variables
}

\author{
Nilgün Öztürk \\ Inönü University, Malatya, Turkey
}

\begin{abstract}
The purpose of this study is to investigate whether the friendship qualities of 9-12 years old students differ according to socio-demographic variables. The study group consisted of 667 students attending the $3^{\text {rd }}, 4^{\text {th }}, 5^{\text {th }}$ and $6^{\text {th }}$ grades of the schools in the Battalgazi district of Malatya in the 2018-2019 academic year. A personal information form prepared by the researcher to collect demographic data and the Friendship Quality Scale were used to measure friendship quality levels. In the data analysis, mean, independent sample $t$ test, oneway analysis of variance (ANOVA) were used. According to the findings, it was found out that the dimensions of friendship quality, which students attach the most importance to, were trust, validation and support, self-disclosure, conflict, companionship and recreation; the least important the dimension of friendship quality is the help and guidance. According to the of gender, grade level, academic achievement and economic status, there is a significant difference in of the students' friendship quality. According to gender, female students' friendship quality was found to be higher levels than male students. As the grade level progresses, the friendship quality of the students increases. It has been found that the increase in academic achievement of students positively affects the quality of friendship. It was observed that the increase in the economic status of the students positively reflects the friendship quality.
\end{abstract}

\section{Suggested Citation:}

Öztürk, N. (2019). Assessing the Friendship Quality of Children between the Ages of 9 and 12 Based on Certain Variables, International Journal of Academic Research in Education, 5(1), 9-24. DOI: 10.17985/ijare.599837

\footnotetext{
${ }^{1}$ Inonu University, Faculty of Education, Department of Guidance and Psychological Counseling. nilgun.ozturk@inonu.edu.tr
}

Submitted

Revised

14 August 2019

Accepted

31 August 2019

Keywords:

Friendship,

Friendship quality,

Pre-adolescence. 


\section{INTRODUCTION}

Close peer relations begin to form in childhood and constitute a significant milestone in the developmental process (Collins \& Russell, 1991). Since peer relations comprise the foundation of social life, individuals exert great endeavors to create and maintain friendships (Brannan, Biswas-Diener, Mohr, Mortazavi \& Stein, 2013). Friendship, which includes different levels of accompaniment, intimacy, sympathizing with another individual and mutual assistance, is defined as a qualitative relationship that expresses voluntarily commitment between two individuals with the intention to meet individual socioemotional objectives (Hays, 1988). Peer relation is significant for emotional health and development (Wiltz, 2005) and serves various emotional needs (La Greca, Bearman \& Moore, 2002). Friends contribute to coping with stress (Berndt \& Keefe, 1995), increased psychological well-being and harmony (Bukowski, Laursen \& Hoza 2010), increased levels of happiness (Demir, Özdemir \& Weitekamp, 2007) and decreased levels of loneliness and depression (Burk \& Laursen 2005). Hence, friendship plays an important role in the social life and harmony of all children (Bayhan \& Işıtan, 2010; Ladd, Konchenderfer \& Coleman, 1996; Piehler \& Dishion, 2007). Children first establish contact with their parents, afterwards with other adults and children. Peer relations for children is a continuation of the bond they initially established with their mothers. Individuals need to connect another individual who is loved and is special for them, hence convey these needs to peer relations (Thompson, Grace and Cohen, 2002). Pre-adolescent period (9-12) brings many biological and psycho-social changes (Petersen, 1987). During this period, children become sincere with their friends and establishing emotional closeness manifests itself as a significant need (Berndt, 1981; Chow, 2008; Erdley, Nagle, Newman, \& Carpenter, 2001; Furman \& Biermen, 1984; Geçtan, 2003; Sullivan 1953). Furthermore, Sullivan (1953) argues that establishing a close peer relation during pre-adolescence is an important developmental task and that the need to be accepted is satisfied through peer relations.

Friendship quality, on the other hand, is defined as the degree of success on the account of both positive (intimacy, cooperation, loyalty, safety, support, prosocial behaviors) and negative aspects (conflict, supremacy, competition) (Berndt, 2002; Ladd, 1999; Piehler \& Dishion, 2007). Therefore, positive characteristics are considered to be more in a high-quality friendship and the negative aspects are less experienced (Phebe, 2007). There are research findings indicating in literature that having a high friendship quality contributes to children's lives both academically and socially (Berndt, Hawkins \& Jiao, 1999; Ladd et al., 1996). Studies on friendship demonstrated that friends were capable of influencing students' attitudes and beliefs about school as much as their academic achievement (Agnor, 2009; Cauce, 1986; Ide, Parkerson, Haertel \& Walberg, 1981). Cevik's (2007) study in high school students sample shows that being succesfull is preferred characteristics in the relationship of friendship. Saçar (2007) says that academically successful children attracts more attention than their friends. Flashman, (2012) says that academic achievement may be an important mechanism for friendships. Therefore, the findings obtained from the researches suggest that children who are academically successful can establish more successful friendship relationships.

Another factor that affects the friendship quality and development of children is age (Bayhan \& Işıtan, 2010; Mitchell, 2005; Newcomb \& Bagwell, 1995) and grade level (Berndt \& Perry, 1986). Hallinan (1979) states that grade levels is effective on friendship structure of children. With increasing age, the expectations of children from their friends change (Mitchell, 2005), thus both the friendship quality and the friendship quantity change (Bayhan \& Işıtan, 2010). In order to comprehend childhood friendship, it is essential to take into consideration that children in different ages have different skills regarding friendship (Thompson, Grace \& Cohen, 2002). It is noteworthy that, during the developmental process, the choice of friends in preschool and kindergarten is based on cognitive development, and concrete 
events and features are not considered as significant criteria due to the cognitive development period. Such criteria are being in the same class, being in the same school bus, and enjoying the same activities. The friendships developed during the elementary school is based on agreement (Mitchell, 2005). During this period, it is observed that children tend to participate more in group games, thus become less selfish and aggressive, attain a stronger group consciousness and become more helpful (Yavuzer, 1998). Yet, in adolescence, agreement (Legerski, 2010), self-disclosure (McFarland, 2008), loyalty (Weiss \& Smith, 2002) and emotional support (Furman \& Buhrmester 1985) become more important. It is considered significant that peer relations and the quality of these relations change based on age and grade level.

Furthermore, there exist differences in friendship quality based on gender (Brendgen, Markiewicz, Doyle \& Bukowski, 2001; Rose \& Asher, 1999; Weiss \& Smith, 2002), given that gender is an important social structure that shapes the perceptions towards peer relations and interactions (Berndt \& Perry, 1986; Feiring \& Lewis, 1989). Young females are highly interested in self-disclosure in peer relations and they are more successful in approval, support and conflict resolution (Parker \& Asher 1993), intimacy and cooperation (Bukowski, Hoza \& Boivin 1994). However, young males were more interested in participating similar activities with their peers (Chow, 2008), and being in large groups for peer relations (Maccoby, 1990). The studies of Lansford and Parker (1999) indicated that young females exhibited less aggressive behaviors when compared to young males $\left(3^{\text {rd }}, 4^{\text {th }}\right.$ and $5^{\text {th }}$ grades) in peer relations. According to Parker and Asher (1993), young males encountered more difficulty in conflict resolution in peer relations when compared to young females and it was observed that they were more likely to compete with their peers (Berndt, 1981).

Besides the emphasis that above-mentioned factors could lead to friendship quality differences (Maccoby, 1990), peer relations could be affected by factors such as inadequate economic level of the family or job loss, and a child who is subject to such factors could withdraw from their peers (Elder, Van Nguyen \& Capsi, 1985; McLoyd, 1989). It is acknowledged that economic problems are related to various physical and psychological health problems in children, adolescents and adults (Aldwin \& Revenson, 1986). Such economic problems encountered in families could result with more depressed and alone children (Lempers, Clark-Lempers \& Simons, 1989). Therefore, it is considered that economic situation affects peer relations.

Parallel to the above-mentioned scope, there exist studies on socio-demographic structures (gender, age/grade level, academic achievement, socio-economic levels) that affect friendship quality in international literature. A review on Turkey's literature, on the other hand, revealed that there existed no studies on socio-demographic structures that affect friendship quality, hence the subject area was overlooked. In addition, it is stated that social relations are influenced by cultural differences (Hartup, 1984; Kito, 2005; Verkuyten ve Steenhuis, 2005). Since cultural factors affect social relations, it is considered that it is important to investigate sociodemographic variables. In Turkish scientific literature, there exist studies that focus on the factors related to friendship with some particular findings, yet these studies commonly targeted adults and adolescents. Self-esteem (Çevik, 2007), parents' attitudes (Dinçer, 2008), development of friendship in adolescence (Çok, 1993), factors affecting couples in marriage and peer relations (Yılmazçoban, 2011), the relationship between friendship environment and job satisfaction (Erdil, Keskin, Imamoglu \& Erat, 2011) were some of the studied variables.

Peer relations and the quality of these relations are considered significant due to the importance of social, emotional and behavioral development of children and adolescents (Newcomb \& Bagwell, 1995; Parker \& Asher, 1993). However, it is remarkable that studies conducted on friendship in Turkey, mostly focused on adults or adolescents and there exists no research focusing on children. However, childhood experiences are capable of affecting the experiences of an individual in adulthood (Asher \& Parker, 1988; Schneider, 2000; Wanless \& Prinz, 1982). Therefore, it is considered important that the individual factors 
that affect the friendship quality of the relationship, which is important in the life and social development of pre-adolescent children (9-12) are addressed and investigated.

\section{Purpose of the study}

The main purpose of the present study is to examine friendship qualities of children between the ages of 9 to 12 based on certain variables. Therefore, the present study was intended to seek the answers to the following questions: Does the friendship quality level of students exhibit a significant difference based on,

1. Gender,

2. Grade level,

3. Academic achievement,

4. Socio-economic levels.

\section{METHOD}

\section{Research Design}

The present study, which was conducted to determine the effect of the gender, grade level, academic achievement and socioeconomic level variables on the friendship quality of students between the age of 9 and 12, was designed as a causal comparison research. Causal comparative research is a research method that aims to determine the causes of an existing situation or event and the variables affecting these causes or the results of an effect (Büyüköztürk, Çakmak, Akgün, Karadeniz \& Demirel, 2010).

\section{Participants}

The universe of the present study comprised the $5^{\text {th }}$ and $6^{\text {th }}$ grade students in secondary schools and the $3^{\text {rd }}$ and $4^{\text {th }}$ grade students in the elementary schools in Malatya Province, Turkey. The sample was composed of 677 students attending elementary and secondary schools in Malatya city center during the 2018-2019 academic year. Convenience sampling method (Fraenkel, Wallen \& Hyun, 2012) was used in determination of the sample. Convenience sampling refers to the easy accessibility and applicability in working with samples (Fraenkel et al., 2012). The age average of students constituting the sample is 10.50 and the range is between the ages of 9 and 12. Table 1 presents the frequency and percentage distributions based on the demographic characteristics of students. 
Table 1. Frequency and Percentage Distributions Based on the Demographic Characteristics of Students

\begin{tabular}{lccc}
\hline & Categories & $f$ & $\%$ \\
\hline Gender & Famele & 378 & 55,8 \\
Grade level & Male & 299 & 44,2 \\
& $3^{\text {rd }}$ grade & 123 & 18,2 \\
& $4^{\text {th }}$ grade & 134 & 19,8 \\
& $5^{\text {th }}$ grade & 175 & 25,8 \\
Academic achievement & $6^{\text {th }}$ grade & 245 & 36,2 \\
& Low & 24 & 3,5 \\
& Moderate & 108 & 16,0 \\
Economic Level of Their Families & Good & 195 & 28,8 \\
& Very good & 350 & 51,7 \\
& Low & 68 & 10,0 \\
Total & Medium & 169 & 25,0 \\
& Good & 244 & 36,0 \\
& Very good & 196 & 29,0 \\
\hline
\end{tabular}

Table 1 presents the distributions based on the demographic characteristics of students. The distribution by gender indicated that 378 (55,8\%) students were female and $299(44,2 \%)$ were male. Based on grade level, 123 (18.2\%) students were in the 3rd grade, 134 (19.8\%) were in the 4th grade, 175 (25.8\%) were in the 5 th grade and $245(36.2 \%)$ were in the 6th grade. The distribution by academic achievement indicated that 24 (3.5\%) students perceived their academic achievement as low, 108 (16.0\%) as moderate, 195 (28.8\%) as good and 350 (51.7\%) perceived their academic achievement as very good. The distribution by socio-economic level indicated that 68 (10.0\%) students perceived their families economic level as low, 169 (25.0\%) as medium, 244 (36.0\%) as good and 196 (29.0\%) of the students perceived their economic level as very good.

\section{Data Collection Tools}

The data of the present study were collected during the Fall Semester of the 2018-2019 academic year. Personal information form, prepared by the researcher, was utilized to collect the data regarding the gender, grade level, academic achievement, and socioeconomic level of the students. The Friendship Quality Scale (FQS) was used to determine the friendship quality of the students.

The Friendship Quality Scale (FQS): The scale was developed by Asher and Parker (1993) to identify the friendship quality of children and was adapted in Turkish language by Öztürk (2016), after completing the validity and reliability studies. In the scale, children mark their responses for each item on a 5-point scale. These 5-points are (0) not true at all, (1) true to a degree, (2) true, (3) quite true and (4) completely true. Friendship quality scale is composed of six dimensions, which are self-disclosure (sample item $=1$ recall a lot of secrets we told each other with my friend), conflict (sample item = We discuss a lot with my friend), approval and support (sample item = My friend makes me feel good about my ideas), friendship and accompaniment (sample item = We always select each other -in games, events- as a partner), trust (sample item = I always trust my friend in keeping his/her promises), help and guidance (sample item = My friend and I help each other in daily errands and various other things). The highest score that can be obtained from the scale is 132 and the lowest is 0 . A high score obtained from the friendship quality scale indicates a high-quality friendship. In terms of the reliability of the inventory, Cronbach's alpha internal consistency coefficient was determined as .89, and test-retest reliability was as .92 for the whole scale. Exploratory and confirmatory factor analysis studies were conducted for the structure validity study of the inventory. The total variance explained by six factors was $51 \%$. Item factor loads were found to be 
between .42 and .87 . Once the fit indices of the model were examined, it was found that RMSEA $=.042$, $\mathrm{GFI}=.92, \mathrm{AGFI}=.90, \mathrm{CFI}=.92, \mathrm{NNFI}=.91, \mathrm{SRMR}=.04, \mathrm{RMR}=.069, \mathrm{PGFI}=.78, \mathrm{PNFI}=.78$ (Öztürk, 2016).

\section{Data Analysis}

Subsequent to retrieving the data through the data collection tools utilized in the present research, the data were prepared for analysis. The present study preliminarily reached 950 students. During the application, control items (sample control item = check the correct choice) were inserted within the measurement instrument. The main purpose in using control items stemmed from the approach to check whether the students completed the scale items through reading them. In creating the data set, the students who filled the control items incorrectly were excluded. As a result of this process, the data set consisted of 690 students.

Variance analysis assumptions were reviewed before commencing with the analysis of research data. Extreme values were examined during the preparation stage of the data. Standardized $Z$ scores were used for the examination of extreme values. $Z$ score range should be between -3 and +3 points (Çokluk, Şekercioğlu \& Büyüköztürk, 2010). Data outside the -3 to +3 range for the standardized $Z$ scores were excluded from the data set. Furthermore, Skewness and kurtosis coefficients were examined to achieve the normality criterion, the range of +1 to -1 was taken into consideration. Levene test was also used to test the homogeneity. With respect to these examinations, 677 students remained in the data set due to the removal of extreme values to ensure normality. Based on the examination of the fundamental assumptions of variance analysis, it was concluded that the assumptions were met.

In the present study, t-test was used in binary groups and One-Way Variance Analysis (ANOVA) technique was used for more than two independent groups with the aim to determine the relationship between the friendship quality scale scores of the children and certain demographic variables. In groups, which exhibited significant difference based on the ANOVA test, "Tukey" test was used to determine in which group, or between which groups the difference was (Çokluk et al., 2010).

\section{FINDINGS}

\section{Findings on the Gender of the Children}

The results of the t-test conducted to determine whether the friendship quality of the children differed based on gender are presented in Table 2.

Table 2. The t-test results on friendship quality based on gender

\begin{tabular}{llllll}
\hline & Gender & $\overline{\mathbf{x}}$ & Ss & $\mathrm{t}$ & $\mathrm{p}$ \\
\hline Friendship Quality & Female & 94.25 & 22.99 & 3.62 & .010 \\
& Male & 87.43 & 25.80 & & \\
\hline
\end{tabular}

$p<.05$

As seen in Table 2, the mean friendship quality scale scores of the females was $\bar{X}=94.25(\mathrm{Sd}=22.99)$, while the mean friendship quality scale scores of the females was $\bar{X}=87.43(\mathrm{Sd}=25.80)$. As a result of the independent groups $t$ test, it was determined that the difference between the arithmetic mean of the groups was statistically significant $(t=3.62 ; p<.05)$. This finding demonstrated that the friendship quality of the females was higher and the gender variable affected the friendship quality of children. 


\section{Findings on the Grade Level of Children Variable}

The results of the one-way analysis of variance (ANOVA) conducted to investigate whether the children 's friendship quality varied based on the grade level are presented in Table 3.

Table 3. One-way analysis of variance (ANOVA) results for friendship quality based on grade level variable

\begin{tabular}{|c|c|c|c|c|c|c|c|c|c|c|}
\hline & Grade level & $\overline{\mathbf{x}}$ & Ss & & $\begin{array}{l}\text { Sum of } \\
\text { Squares }\end{array}$ & $\mathrm{df}$ & $\begin{array}{l}\text { Mean } \\
\text { Square }\end{array}$ & $\mathrm{F}$ & $p$ & $\begin{array}{l}\text { Meaningful } \\
\text { difference }\end{array}$ \\
\hline Friendship & $3^{\text {rd Grade }}$ & 86.10 & 22.32 & $\begin{array}{c}\text { Between } \\
\text { Groups }\end{array}$ & 14715.299 & 3 & 4905.100 & & & $3^{\text {rd }}-4^{\text {th } *}$ \\
\hline \multirow[t]{3}{*}{ Quality } & $4^{\text {th }}$ Grade & 97.56 & 24.01 & $\begin{array}{l}\text { Within } \\
\text { Groups }\end{array}$ & 390915.997 & 673 & 580.856 & 8.445 & .000 & $3^{\text {rd }}-5^{\text {th } *}$ \\
\hline & $5^{\text {th }}$ Grade & 95.20 & 25.08 & Total & 405631.297 & 676 & & & & $4^{\text {th }}-6^{\text {th }} *$ \\
\hline & $6^{\text {th }}$ Grade & 91.24 & 24.49 & & & & & & & $5^{\text {th }}-6^{\text {th }} *$ \\
\hline
\end{tabular}

$p<.005$

As seen in Table 3, the mean friendship quality scale score of $3^{\text {rd }}$ grade students was $\bar{x}=86.10,(\mathrm{Sd}=$ $22.32)$, the mean friendship quality scale score of $4^{\text {th }}$ grade students was $\bar{x}=97.56,(S d=24.01)$, the mean friendship quality scale score of $5^{\text {th }}$ grade students was $\bar{x}=95.20,(S d=25.08)$, and the mean friendship quality scale score of $6^{\text {th }}$ grade students was $\bar{X}=91.24(\mathrm{Sd}=24.49)$. It was found that the difference between the arithmetic means of the friendship quality scale based on grade level was statistically significant $\left(F_{(3-673)}=8.445, p<.05\right]$. To determine the presence of a significant difference among the groups, the Tukey Test was conducted, and it was observed that there was a difference between 3 rd grade and 4th grade, 3rd grade and 5th grade, 4th grade and 6th grade, and 5th grade and 6 th grade. These findings indicated that the grade level variable affected the friendship quality of children.

\section{Findings on the Academic Achievement Level of the Children}

The results of one-way analysis of variance (ANOVA) conducted to determine whether there was a difference between friendship quality of the children based on academic achievement levels are presented in Table 4.

Table 4. One-way analysis of variance (ANOVA) results for friendship quality based on academic achievement variable

\begin{tabular}{|c|c|c|c|c|c|c|c|c|c|c|}
\hline & $\begin{array}{c}\text { Academic } \\
\text { achievement }\end{array}$ & $\overline{\mathbf{x}}$ & Ss & & $\begin{array}{l}\text { Sum of } \\
\text { Squares }\end{array}$ & $d f$ & $\begin{array}{l}\text { Mean } \\
\text { Square }\end{array}$ & $\mathrm{F}$ & $p$ & $\begin{array}{c}\text { Meaningful } \\
\text { difference }\end{array}$ \\
\hline Friendship & Weak & 77.41 & 21.29 & $\begin{array}{c}\text { Between } \\
\text { Groups }\end{array}$ & 23225.760 & 3 & 7741.920 & & & $\begin{array}{l}\text { Low-very } \\
\text { good* }\end{array}$ \\
\hline \multirow[t]{3}{*}{ Quality } & Middle & 83.54 & 24.89 & $\begin{array}{l}\text { Within } \\
\text { Groups }\end{array}$ & 382405.537 & 673 & 568.210 & 13.625 & .000 & $\begin{array}{l}\text { Moderate- } \\
\text { very good* }\end{array}$ \\
\hline & Good & 87.71 & 24.13 & Total & 405631.297 & 676 & & & & $\begin{array}{l}\text { Good- very } \\
\text { good* }\end{array}$ \\
\hline & Very good & 96.53 & 23.49 & & & & & & & \\
\hline
\end{tabular}

$p<.005$

As seen in Table 4, the mean friendship quality scale score of the students with low academic achievement was $\bar{x}=77.41$, (Sd $=21.29)$, the mean friendship quality scale score of the students with moderate academic achievement was $\bar{X}=83.54$, $(\mathrm{Sd}=24.89)$, the mean friendship quality scale score of the students with good academic achievement was $\bar{X}=87.71$, (Sd $=24.13$ ), and the mean friendship quality scale score of the students with very good academic achievement was $\bar{x}=96.53,(\mathrm{Sd}=23.49)$. It 
was found that the difference between the arithmetic mean of academic achievement variable was statistically significant $\left[F_{(3-673)}=13.625, p<.05\right]$ based on the one-way analysis of variance (ANOVA) analysis conducted to determine whether there was a difference between friendship quality of the children based on academic achievement. To determine the presence of a significant difference among the groups, the Tukey Test was conducted, and it was observed that there was a difference between low academic achievement and very good academic achievement, between moderate academic achievement and very good academic achievement, and between good academic achievement and very good academic achievement. These findings demonstrated that academic achievement affected the friendship quality of the children.

\section{Findings on the Economic Status of the Children}

The results of one-way analysis of variance (ANOVA) conducted to determine whether there was a difference between friendship quality of the children based on economic status are presented in Table 5.

Table 5. One-way analysis of variance (ANOVA) results for friendship quality based on socioeconomic status variable

\begin{tabular}{|c|c|c|c|c|c|c|c|c|c|c|}
\hline & $\begin{array}{c}\text { Economic } \\
\text { status }\end{array}$ & $\overline{\mathbf{x}}$ & Ss & & $\begin{array}{l}\text { Sum of } \\
\text { Squares }\end{array}$ & $d f$ & KO & $F$ & $p$ & $\begin{array}{l}\text { Meaningful } \\
\text { difference }\end{array}$ \\
\hline Friendship & Low & 82.57 & 25.68 & $\begin{array}{c}\text { Between } \\
\text { Groups }\end{array}$ & 7502.150 & 3 & 2500.717 & & & Low-good* \\
\hline \multirow[t]{3}{*}{ Quality } & Middle & 90.21 & 23.78 & $\begin{array}{l}\text { Within } \\
\text { Groups }\end{array}$ & 398129.147 & 673 & 591.574 & $\begin{array}{c}4.22 \\
7\end{array}$ & .006 & $\begin{array}{l}\text { Low- very } \\
\text { good* }\end{array}$ \\
\hline & Good & 91.71 & 25.98 & Total & 405631.297 & 676 & & & & \\
\hline & Very good & 94.56 & 22.05 & & & & & & & \\
\hline
\end{tabular}

As seen in Table 6, the mean friendship quality scale score of the students with low economic status was $\bar{X}=82.57$ (Ss $=25.68$ ), the mean friendship quality scale score of the students with medium economic status was $\bar{X}=90.21$, (Sd $=23.78)$, the mean friendship quality scale score of the students with good economic status was $\bar{X}=91.71$, (Ss $=25.98)$, and the mean friendship quality scale score of the students with very good economic status was $\bar{X}=94.56$, $(\mathrm{Sd}=22.05)$. It was found that the difference between the arithmetic mean of the economic status variable was statistically significant $[F(3-673)=4.227, p<.05]$. To determine the presence of a significant difference among the groups, the Tukey Test was conducted, and it was observed that there was a difference between low economic status and good economic status and between low economic status and very good economic status. These findings demonstrated that economic status affected the friendship quality of the children.

\section{DISCUSSION \& CONCLUSION}

The present study was intended to examine the friendship quality of the students between the ages of 9 and 12 based on certain variables. According to the results of the study, it was concluded that friendship quality of the students between the ages of 9 and 12 varied based on gender, grade level, academic achievement and socioeconomic level.

The findings of the present study included that friendship quality differed significantly based on gender and that the mean friendship quality of female students was higher than that of male students. Similar findings exist in literature indicating that friendship quality differs based on gender in the preadolescence period (Berndt, 1982; Berndt \& Keefe, 1995; Buhrmester \& Furman, 1987; Furman \& 
Buhrmester, 1992; Laird, Pettit, Dodge \& Bates, 1999). Other studies supporting the findings of the present study demonstrated that friendship qualities of young females were higher when compared to young males (Brendgen et al., 2001; Rose \& Asher, 1999). Furthermore, research findings, indicating that friendship quality differed based on the gender variable and friendships among females were closer to that of males in pre-adolescence (Berndt, 1982; Berndt \& Perry, 1986; Weiss \& Smith, 2002) and that there existed less disagreement in peer relations (Phillipsen, 1999), stood out. In the studies of Bukowski et al. (1994), it was established that females were more likely to exhibit intimacy, help, approval, trust, friendship and companionship compared to males. Parker and Asher (1993) emphasized in their study that conflict resolution, approval and intimacy levels were lower in males than that of females, and females indicated more pro-social behaviors compared to males. Another study exhibited that females attached more importance to their friendships than males and they could be more sensitive when encountering problems (Gore, Aseltine \& Colten, 1993). According to Maccoby (1990), differences in communication methods and playing preferences explained the gender related differences in peer relations. Maccoby (1990) stated that females preferred to communicate more politely in pre-adolescent friendships, while males preferred the forms of order and request more. According to Benenson and Christakos (2003), while females were inclined to spend more time in bilateral relations, males preferred more to be together in groups. During this period, males were more inclined to playing sports together (Weiss \& Smith, 2002). Higher level of intimacy, help, approval, trust and companionship and higher importance attached to peer relations in females explain the higher levels of friendship quality in females.

Once the friendship quality of the students were examined based on grade level, it was observed that there was a significant difference between the students in $3^{\text {rd }}$ and $4^{\text {th }}$ grades, $3^{\text {rd }}$ and $5^{\text {th }}$ grades, $4^{\text {rh }}$ and $6^{\text {th }}$ grades and $5^{\text {rh }}$ and $6^{\text {th }}$ grades. Therefore, it could be argued that students with lower grade levels had lower friendship quality compared to upper grade students. It is possible to assert that level of friendship quality commonly increased due to the progress in age. A relevant study by Jones and Dembo (1989) indicated that intimacy increased with the progressing ages of children. Once the friendship of children between the ages of 9 and 10 and 11 and 12 were compared, it was found that the children expressed more intimacy between the ages of 11 and 12. Another study conducted on adolescents evaluated the peer relations of the $7^{\text {th }}$ and $10^{\text {th }}$ grade students and concluded that self-disclosure level increased in upper grade levels. Increasing the level of self-disclosure in adolescence was considered to be a sign of deepening in peer relations (McFarland, 2008). Weiss and Smith (2002) stated that close friendship and intimacy were more important for the adolescent age group between 14 and 18 and it was also more important to spend time and conduct activities together for the athlete age group between 10 and 13. According to Bigelow (1977) children in $2^{\text {rd }}$ and $3^{\text {th }}$ grade levels were in the phase of punishment and reward. The expectation of something in return is quite strong for children at these levels. Children in $4^{\text {rd }}$ and $5^{\text {th }}$ grade levels are at the level of normative expectations. During this period, affectionate children influence their friends. Therefore, values and rules of the affectionate are taken into consideration in peer relations. Children in $6^{\text {rd }}$ and $7^{\text {th }}$ grade levels are more powerfully inclined to self-disclosure and intimacy. Bigelow (1977) stated that the higher the grade level, the lower the expectation of mutual activation and intimacy in friendship becomes more important. Such changes explain the low level of friendship quality of the students with lower grade levels.

Once the friendship quality of the students was examined based on academic achievement, it was observed that there was a significant difference between the students with low and very good academic achievement, with moderate and very good academic achievement and with good and very good academic achievement. It is possible to state that the increase in academic achievement positively reflects the friendship quality of the students. There exist studies in literature that exhibited similar findings with the present study, indicating that the quality of friendship was related to academic achievement (Agnor, 2009; Baker, 2009; Nelson \& DeBacker, 2008). Furthermore, Berndt and Keefe (1995) stated that high level of academic achievement and high-quality friendship were related. Flashman 
(2012) examined the impact of academic achievement on friendship between 7-12 year-old students. In this study, it was seen that academic success affects friendship relationship. According to Yun Lee (2008), low friendship quality reduces school attendance rate. According to Baker (2009), the positive components of friendship quality, such as approval, favorably supported children's attitude towards school. Children with a high-quality friendship level were likely to be approved at school and received greater intimacy and guidance in encountering problems or difficulties regarding academic achievement. According to Ladd (1990), children who were rejected by their peers were more likely to develop negative thoughts towards the school, to reject school and experience academic under achievement throughout the year. Therefore, friendship quality is considered as an important factor that positively affects academic achievement and attachment to school (Cook, Deng \& Morgano, 2007). It is considered that several attitudes, such as accepting approval and help, delivering help when necessary, developing positive attitudes towards school and being capable of cooperation, were considered to affect the academic achievement of the students with high-quality friendship levels.

Once the friendship quality of the students was examined based on their economic situation, it was observed that there was a significant difference between the students with a low and good economic level and with a low and very good economic level. Commonly, it became possible to assert that level of friendship quality increased with respect to the increasing economic levels of the students. Dinçer (2008), who examined the effect of economic level on friendship relationship, concluded that the increasing socio-economic level in adolescents resulted with increased friendship scores. Fong and Isajiw (2000) conducted a study focusing on immigrants and established that socio-economic levels of individuals significantly affected the friendship among ethnic groups. It was observed that individuals with low income level had a poor chance of developing friendship bonds. Fong and Isajiw (2000) also predicted that the social relations of immigrants could develop, and they could be integrated within the society due to increasing individual income levels. Furthermore, Hurtado, Engberg, Ponjuan and Landreman (2002) stated that economic level was important for participating social relations. McLoyd (1989) pointed out that encountered economic problems could affect the socialization of a child and decrease the intimate peer relations. Additionally, Duyan, Duyan, Çifti, Sevin, Erbay ve ikizoğlu (2008) examined the variables that affected the loneliness levels of high school students and concluded that loneliness decreased as the level of income increased. Dodge, Petit and Bates (1994) in their study of how socioeconomic disadvantage affects the socialization of children found that socioeconomic level partially affects the socialization of the individual. It was emphasized that socioeconomic problems could cause changes in life style and daily life of a child and in return cause changes in peer relations. Economic level constitutes a background that affects all life areas and has a significant impact on the cognitive, social and socialization processes of students (Balkar, 2008). It is considered that the social activities, traveling, entertainment, good life and working environment opportunities for students with a good economic level positively affect their peer relations. According to Çakır (2002), it becomes increasingly difficult for an individual and his/her family to participate in social life once their basic needs (food, beverage, housing, health, education) are not met. A continuity in not being able to meet the needs could result in losing the ties with the society. Therefore, it is considered that students who have low socio-economic levels lack various opportunities such as education, social activities, traveling, entertainment, good life and working environment and such inadequacies could create a sense of inhibition in children (Şahin, Batıgün and Uğurtaş, 2002). Such condition explains the low level of friendship quality for the students with lower economic levels.

In conclusion, it was observed that friendship qualities of the students between the ages of 9 and 12 varied based on the variables of gender, grade level, academic achievement and economic status. It is possible to provide certain suggestions with respect to the findings of the present research. First, it was 
observed that male students had lower friendship quality levels compared to female students. Such finding suggests that making necessary planning intended to develop the peer relations of students and attach priority to male students in these planning are essential considerations. Second, although the literature suggests an increase in intimacy (Jones \& Dembo, 1989) due to progressing age, low level of friendship quality among lower grade students could be improved though psychoeducation activities initiated from lower grade level students and such activities could to contribute to further development of relations. Third, given the fact that friendship quality has a positive effect on both academic achievement and attachment to school, psychoeducation activities conducted via the psychological counselors working in school guidance services are recommended to target the establishment, development and continued maintenance of peer relations among students. Fourth, it is recommended that children who live in families with low socioeconomic levels should be trained to provided the skills to develop friendship relations.

Similar to all scientific studies, the present study also has several limitations. The main limitation of the study is the sample group. Since the study group consists of children who are in the pre-adolescence period between the age of 9 and 12, the obtained findings cannot be generalized for other age groups. Another limitation of the present study is to facilitate student perception for the determination of economic level as a demographic variable.

\section{References}

Agnor, C. J. (2009). A proposed model of friendship quality and attachment in preschool children. Doctorate Dissertation. Seattle Pacific University, Seattle.

Aldwin, C. M., \& Revenson, T. A. (1986). Vulnerability to economic stress. American Journal of Community Psychology, 14(2), 161-175.

Asher, S. R., \& Parker, J. G. (1988). Signifance of peer relationship problems in childhood. In B. H. Schneider, G. Attili, J. Nadel \& R. P. Weissberg (Ed.), Social Competence in Develpomental Perspective (pp.5-23). USA Netherlands: Kluwer Academic Publisher.

Baker, S. E. (2009). An examination of friendship quality and affective representations of friendship in childeren perinatally infected with hiv, childern with asthma and healty childern of hiv-positive mothers. Doctorate Dissertation, Central Michigan University, Michigan.

Balkar, B. (2008). Öğrenciler arasındaki sosyal ve ekonomik farklılıkların öğrenci ilişkileri ve öğretim süreci üzerindeki etkisine ilişkin öğretmen görüşleri. Çukurova Üniversitesi Sosyal Bilimler Enstitüsü Dergisi, 17(3), 29-46.

Bayhan, P., \& Işıtan, S. (2010). Ergenlik döneminde ilişkiler: Akran ve romantik ilişkilere genel bakış. Family and Society, 5(20), 33-44.

Berndt, T. J. (1981). Age changes and changes over time in prosocial intentions and behavior between friends. Developmental Psychology, 17(4), 408.

Berndt, T. J. (1982). The features and effects of friendship in early adolescence. Child Development, 14471460.

Berndt, T. J., \& Perry, T. B. (1986). Childrens' perceptions of friendships as supportive relationships. Developmental Psychology, 22, 640-648.

Berndt, T. J., \& Keefe, K. (1995). Friends' influence on adolescents' adjustments to school. Child Development, 66, 1312-1329. doi:10.2307/1131649. 
Berndt, J. J., Hawkins, J. A., \& Jiao, Z. (1999). Influences of friends and friendship on adjustment to junior high school. Merril-Palmer Quarterly, 45(1), 13-41.

Berndt, T. J. (2002). Friendship quality and social development. Current Directions in Psyhological Science, $11(1), 7-10$

Benenson, J. F., \& Christakos, A. (2003). The greater fragility of females' versus males' closest same-sex friendships. Child Development, 74(4), 1123-1129.

Bigelow, B. J. (1977). Children's friendship expectations: A cognitive-developmental study. Child Development, 48, 246-253.

Brannan, D., Biswas-Diener, R., Mohr, C. D., Mortazavi, S., \& Stein, N. (2013). Friends and family: A crosscultural investigation of social support and subjective well-being among college students. The Journal of Positive Psychology, 8(1), 65-75.

Brendgen, M., Markiewicz, D., Doyle, A. B., \& Bukowski, W. M. (2001). The relations between friendship quality ranked-friendship preference and adolescents' behavior with their friends. Merril- Palmer Quarterly, 47(3), 395-415.

Bukowski, W. M., Hoza, B., \& Boivin, M. (1994). Measuring friendship quality during pre-and early adolescence: The development and psychometric properties of the Friendship Qualities Scale. Journal of Social and Personal Relationships, 11(3), 471-484.

Bukowski, W. M., Laursen, B., \& Hoza, B. (2010). The snowball effect: Friendship moderates escalations in depressed affect among avoidant and excluded children. Development and Psychopathology, 22(4), 749-757.

Buhrmester, D., \& Furman, W. (1987). The development of companionship and intimacy. Child Development, 1101-1113.

Burk, W. J., \& Laursen, B. (2005). Adolescent perceptions of friendships and their associations with individual adjustment. International Journal of Behavioral Development, 29,156-164.

Büyüköztürk, Ş., Çakmak, E. K., Akgün, Ö. E., Karadeniz, Ş., \& Demirel, F. (2010). Bilimsel araştırma yöntemleri (7. Basım). Ankara: Pegem Academy Publishing.

Cauce, A. M. (1986). Social networks and social competence: Exploring the effects of early adolescent friendships. American Journal of Community Psychology, 14(6), 607-628.

Collins, W. A., \& Russell, G. (1991). Mother-child and father-child relationships in middle childhood and adolescence: A developmental analysis. Developmental Review, 11 (2), 99-136.

Cook, T. D., Deng, Y., \& Morgano, E. (2007). Friendship influences during early adolescence: The special role of friends' grade point average. Journal of Research on Adolescence, 17(2), 325-356.

Chow, W. Y. (2008). The role of friendship on adolescent mental health problems. Doctorate Dissertation, Arizona State University, Arizona.

Çakır, Ö. (2002). Sosyal dışlanma. Journal of Dokuz Eylül University Institute of Social Sciences, 4(3), 83104.

Çevik, G. B. (2007). Lise 3. sınıf öğrencilerinin arkadaşlık ilişkileri ve benlik saygılarının bazı değişkenler açısından incelenmesi. Yüksek Lisans Tezi, Çukurova Üniversitesi, Adana. 
Çok, F. (1993). Gençlikte arkadaşlık ilişkileri. Education and Science, 17(89), 27-35.

Çokluk, Ö., Şekercioğlu, G., \& Büyüköztürk, Ş. (2010). Sosyal bilimler için çok değişkenli istatistik. SPSS ve LISREL uygulamaları (2. Basım). Ankara: Pegem Academy Publishing.

Demir, M., Özdemir, M., \& Weitekamp, L. A. (2007). Looking to happy tomorrows with friends: Best and close friendships as they predict happiness. Journal of Happiness Studies, 11, 243-253.

Dinçer, B. (2008). Alt ve üst sosyo-ekonomik düzeyde lise ikinci sınıfa devam eden ergenlerin anne baba tutumlarını algılamaları ile arkadaşlık ilişkilerinin incelenmesi. Yüksek Lisans Tezi, Ankara Üniversitesi, Ankara.

Dodge, K. A., Pettit, G. S., \& Bates, J. E. (1994). Socialization mediators of the relation between socioeconomic status and child conduct problems. Child Development, 65(2), 649-665.

Duyan, V., Duyan, G. Ç., Çifti, E. G., Sevin, Ç., Erbay, E., \& Ikizoğlu, M. (2008). Lisede okuyan öğrencilerin yalnızlık durumlarına etki eden değişkenlerin incelenmesi. Education and Science, 33(150), 28-41.

Elder Jr, G. H., Van Nguyen, T., \& Caspi, A. (1985). Linking family hardship to children's lives. Child Development, 361-375.

Erdil, O., Keskin, H., İmamoğlu, S. Z., \& Erat, S. (2011). Yönetim tarzı ve çalışma koşulları, arkadaşlık ortamı ve takdir edilme duygusu ile iş tatmini arasındaki ilişkiler: Tekstil sektöründe bir uygulaması. Doğuş Üniversitesi Dergisi 5(1), 17-26.

Erdly, C. A., Nagle, D. W., Newman, J. E., \& Carpenter, E. M. (2001). Childeren's friendship experiences and psychological adjustment: Theory and Research. Child and Adolescent Developmental, 91, 524.

Feiring, C., \& Lewis, M. (1989). The social networks of girls and boys from early through middle childhood. Children's Social Networks and Social Supports, 119-150.

Flashman, J. (2012). Academic achievement and its impact on friend dynamics. Sociology of Education, 85(1), 61-80.

Fong, E., \& Isajiw, W. W. (2000). Determinants of friendship choices in multiethnic society. In Sociological Forum, (2) 249-271.

Furman, W., \& Bierman, K. L. (1984). Children's conceptions of friendship: A multimethod study of developmental changes. Developmental Psychology, 20(5), 925-931.

Furman, W., \& Buhrmester, D. (1985). Children's perceptions of the personal relationships in their social networks. Developmental psychology, 21(6), 1016.

Furman, W., \& Buhrmester, D. (1992). Age and sex differences in perceptions of networks of personal relationships. Child Development, 63(1), 103-115.

Fraenkel, J. R., Wallen, N. E., \& Hyun, H. H. (2012). How to design and evaluate researchin education (8th ed.). New York: McGraw Hill.

Geçtan, E. (2003). Psikanaliz ve sonrası (7.Basım). İstanbul: Remzi Bookstore.

Gore, S., Aseltine Jr, R. H., \& Colten, M. E. (1993). Gender, social-relationship involvement, and depression. Journal of Research on Adolescence, 3(2), 101-125.

Hartup, W. W. (1984). Development during middle childhood the years six to twelve. Washington. D.C.: National Academy Pres. 
Hays, R. B. (1988). Friendship. In S. Duck (Ed.), Handbook of personal relationships: Theory, research, and interventions (pp. 391-408). New York: Wiley.

Hurtado, S., Engberg, M. E., Ponjuan, L., \& Landreman, L. (2002). Students' precollege preparation for participation in a diverse democracy. Research in Higher Education, 43(2), 163-186.

Ide, J. K., Parkerson, J., Haertel, G. D., \& Walberg, H. J. (1981). Peer group influence on educational outcomes: A quantitative synthesis. Journal of Educational Psychology, 73(4), 472.

Jones, G. P., \& Dembo, M. H. (1989). Age and sex role differences in intimate friendship durind childhood and adolescence. Merrill-Palmer Quarterly, 35(4),445-462.

Kito, M. (2005). Self-disclosure in romantic relationships and friendships among American and Japanese college students. The Journal of Social Psychology, 145(2), 127-140.

Ladd, G. W. (1990). Having friends, keeping friends, making friends and being liked by peers in the classroom: Pretictors of children's early school adjustment? Child Development, 61(4), 1081-1110.

Ladd, G. N., Konchenderfer, B. J., \& Colomen, C. C. (1996). Friendship quality as a predictor of young children's early school adjustment. Child Development, 67, 1103-1118.

Ladd, G. W. (1999). Peer relationship and social competence during early and middle childhood. Annual Review of Psychology, 50, 333-359.

La Greca, A. M., Bearman, K. J., \& Moore, H. (2002). Peer relations of youth with pediatric conditions and health risks: Promoting social support and healthy lifestyles. Journal of Developmental \& Behavioral Pediatrics, 23 (4), 271-280.

Laird, R. D., Pettit, G. S., Dodge, K. A., \& Bates, J. E. (1999). Best friendships, group relationships, and antisocial behavior in early adolescence. The Journal of Early Adolescence, 19(4), 413-437.

Lansford, J. E., \& Parker, J. G. (1999). Children's interactions in triads: Behavioral profiles and effects of gender and patterns of friendships among members. Developmental Psychology, 35(1), 80-93.

Legerski, J. P. (2010). Just among friends: associations amongemotional expression, friend behavior, and friendshıp quality in early adolescent same-sex friend dyads. Doctorate dissertation, Kansas University, Kansas.

Lempers, J. D., Clark-Lempers, D., \& Simons, R. L. (1989). Economic hardship, parenting, and distress in adolescence. Child Development, 25-39.

Maccoby, E. E. (1990). Gender and relationship: A developmental perspective. American Psychologist, 45(4), 513-520.

McLoyd, V. C. (1989). Socialization and development in a changing economy: The effects of paternal job and income loss on children. American Psychologist, 44(2), 293-302.

McFarland, C. A. (2008). Reciprocal relationships between adolescent aggression and close friendship quality in middle and high school. Doctorate Dissertation, Virginia University, USA.

Mitchell, G. S. (2005). Children's friendship and after-school program participation: Does participation in an after-school program affect the aevelopment and quality of children's friendship. Master Dissertation, Massachusetts University, USA. 
Nelson, R. M., \& DeBacker, T. K. (2008). Achievement motivation in adolescents: The role of peer climate and best friends. The Journal of Experimental Education, 76(2), 170-189.

Newcomb, A. F., \& Bagwell, C. L. (1995). Children's friendship relations: A meta-analytic review. Psychological Bulletin, 117(2), 306.

Öztürk, N. (2016). Arkadaşlık becerisi psiko-eğitiminin 9-12 yaş arası öğrencilerin arkadaşlık niteliğine etkisi. Doktora Tezi, İnönü Üniversitesi, Malatya.

Parker, J. G., \& Asher, S. R. (1993). Friendship and friendship quality in middle childhood: links with peer group acceptance and feelings of loneliness and social dissatisfaction. Developmental Psychology,29, 611- 621.

Petersen, A. C. (1987). The nature of biological-psychosocial interactions: The sample case of early adolescence. In R. M. Lerner \& T. T. Foch (Ed.), Child psychology. Biological-psychosocial interactions in early adolescence (pp. 35-61). Hillsdale, NJ, US: Lawrence Erlbaum Associates, Inc

Phebe, W. F. L. (2007). Peer relations in preadolescence: Associations between friendship guality peer acceptence and parentel management in peer relations. Retrieved 01 January 2019, from http://lbms03.cityu.edu.hk/oaps/ss2007-5790-Ifw768.pdf

Phillipsen, L. C. (1999). Associations between age, gender, and group acceptance and three components of friendship quality. The Journal of Early Adolescence, 19(4), 438-464.

Piehler, T. F., \& Dishion, T. J. (2007). Interpersonal dynamic within adolescencent friendships: Dyadic mutuality, deviant talk, and patterns of antisocial behavior. Child Development, 78(5), 1611-1624.

Rose, A. J., \& Asher, S. R. (1999). Children's goals and strategies in response to conflicts within a friendship. Developmental Psychology, 35(1), 69-79.

Saçar, B. (2007). ilköğretim sekizinci sınıf öğrencilerinin öfke tepkisiyle arkadaş bağlılığının incelenmesi. Yayınlanmamış Yüksek Lisans Tezi, Çukurova Üniversitesi, Adana.

Sullivan, H. S. (1953). The interpersonal theory of psychiatry. New York: Norton.

Schneider, B. H. (2000). Friends and enemies. Peer relations in childhood, London: Arnold.

Şahin, N. H., Batıgün, A. D., \& Uğurtaş, S. (2002). Kısa Semptom Envanteri (KSE): Ergenler için kullanımının geçerlik, güvenilirlik ve faktör yapısı. Türk Psikiyatri Dergisi,13(2), 125-135.

Thompson, M., Grace, C.O., \& Cohen, L. J. (2002). Çocuğunuzun arkadaşlık ilişkileri (2. Basım) (Ekin N. Boylu, trans.). Ankara: Arkadaş Publishing.

Wanless, R. L., \& Prinz, R. J. (1982). Methodological issues in conceptualizing and treating childhood social isolation. Psychological Bulletin, 92, 39-55.

Weiss, M. R., \& Smith, A. L. (2002). Friendship quality in youth sport: Reletionship to age, gender and motivation variables. Journal of Sport \& Exercise Psychology, 24(84), 420-437.

Wiltz, J. M. A. (2005). identifying factors associated with friendship in individuals with mental retardation. Doctorate dissertation, Ohio State University, Ohio.

Verkuyten, M., \& Steenhuis, A. (2005). Preadolescents' understanding and reasoning about asylum seeker peers and friendships. Journal of Applied Developmental Psychology, 26(6), 660-679.

Yavuzer, H. (1998). Ana-baba çocuk (2. Basım). İstanbul: Remzi Kitabevi 
Yılmazçoban, M. (2011). Evlilikte çiftleri etkileyen unsurlar ve arkadaşlık ilkeleri. Yalova Üniversitesi Sosyal Bilimler Dergisi, 1(1), 178-195.

Yun Lee, L. S. (2008). Peer reciprocity, acceptence and friendship quality in chidren with autism in general educational settings. Doctorate Dissertation, California University, Los Angeles. 